\title{
An Overview of Patent Law as Applied to the Field of Veterinary Medicine
}

\author{
James M. Gould ${ }^{1,2}$
}

Received 30 November 2006; accepted 20 November 2007; published online 5 February 2008

Abstract. This article analyzes some of the challenges that can arise when patent law is applied to the field
of veterinary medicine. Topics covered in this article include an overview of the different kinds of
inventions that can be patented in the veterinary field; a review of recent legal developments that may
affect the patenting of veterinary pharmaceuticals; a discussion of some potential issues related to patents
covering assays; and an identification of some special situations where the law affecting veterinary
pharmaceuticals is actually different from the law affecting human pharmaceuticals.

KEY WORDS: animal health; intellectual property; patents; pharmaceuticals; veterinary medicine.

\section{INTRODUCTION}

This article highlights issues that can arise when patent law is applied to the field of veterinary medicine. For the most part, the application of patent law to veterinary pharmaceuticals parallels its application to human pharmaceuticals, with outcomes dependent on the particular facts in each case. In a few areas, however, the law itself is different for veterinary products; and these specific exceptions-in areas such as "patent term restoration" and "safe harbor uses"-are discussed in the final section of this article.

\section{BRIEF OVERVIEW OF THE FUNDAMENTALS OF PATENT LAW}

\section{What is a Patent?}

A patent is a governmental grant of a temporary right to exclude others from making, using, or selling the claimed invention for a limited number of years. As a policy matter, the grant of a patent is sometimes viewed as a quid pro quo, whereby innovation is advanced through full disclosure of a useful invention in exchange for the grant of exclusive rights for the life of the patent. For innovators, the possibility of an exclusive right provides an incentive to invest in research and development. For the public, the full disclosure of inventions in published patent documents expands the general knowledge base and leads to further innovations.

\footnotetext{
${ }^{1}$ Global Law Department, Schering-Plough Corporation, Kenilworth, New Jersey, USA.

${ }^{2}$ To whom correspondence should be addressed. (e-mail: james. gould@spcorp.com)
}

\section{What Kinds of Inventions can be Patented in the Field of Veterinary Medicine?}

Subject matter that is amenable to patent protection in the areas of animal health and veterinary medicine can include:

- A new active ingredient and its use;

- A new process for making an active ingredient (regardless whether the compound is "old" or "new");

- A new form, formulation, or "dosage form" of an old active ingredient;

- A new use of an old active ingredient (e.g., a new indication, new species, new patient subgroup, new dosage regimen, new route of administration, etc.);

- A new combination or mixture of old active ingredients;

- A new vaccine;

- A newly isolated or purified substance;

- A novel isolate from the field;

- Genetically engineered microorganisms, recombinant nucleic acids, polypeptides, recombinant vectors, and transformed cell lines;

- Transgenic animals (e.g., knockout mice, oncogenic mice, etc.);

- Monoclonal antibodies, hybridomas;

- Screening assays for identifying new active ingredients;

- Assays for measuring an animal's traits, or the efficacy or safety of drugs after administration to an animal;

- Methods of diagnosis;

- New devices or packaging;

- New methods of doing business;

- Software; and

- Microchips for implantation. 
What are the Criteria for Patentability?

The major requirements for obtaining a patent are summarized briefly below:

1. Statutory Subject Matter - The subject matter sought to be patented must be of the type that is eligible for patent protection as a matter of law under the applicable patent statute in each jurisdiction. (See list above for examples in the veterinary field under U.S. law).

2. Utility - The invention must be useful and have real world utility; its use must be specific, substantial and credible.(1,2) (The utility requirement is not usually an issue in the veterinary field).

3. Novelty - The invention must be truly new, and cannot have existed beforehand.(3)

4. Non-obviousness - It is not enough for a new invention to be novel-it must also be "non-obvious" to a person having "ordinary skill in the art."(4) In many foreign jurisdictions, the corresponding patentability requirement is referred to as "inventive step". See, e.g., Article 56 of the European Patent Convention. (5)

5. Sufficiency of the Disclosure in the Patent Specification as Filed - U.S. Patent law requires that patent applications disclose the best mode for carrying out the claimed invention and provide adequate written description of how to make and use the invention. With regard to the adequacy of a patent application's written description of how to make and use the invention, contemporary case law in the U.S. highlights two significant tests. The more classic of the two is what is often referred to as "enablement"-this is the more technologically-based test of whether one of ordinary skill in the art could make and use the claimed invention without "undue experimentation". The other major test of adequate disclosure in the U.S. is often referred to as the "written description" requirement. This test is focused on factors such as whether the inventors have shown, through their patent specification (in sufficient wording and detail), that they are truly "in possession" of the invention as claimed.(6)

\section{RECENT DEVELOPMENTS IN THE LAW RELATING TO "SUFFICIENCY OF DISCLOSURE" THAT COULD AFFECT PATENTING IN THE FIELD OF VETERINARY MEDICINE}

\section{Brief Overview of the Requirements Related to Sufficient Disclosure}

In the U.S., the law pertaining to sufficient disclosure is codified in 35 U.S.C. $\S 112$, paragraph 1, which provides that:

The specification shall contain a written description of the invention, and of the manner and process of making and using it, in such full, clear, concise, and exact terms as to enable any person skilled in the art to which it pertains... to make and use the same, and shall set forth the best mode contemplated by the inventor of carrying out his invention.

As indicated above, two major aspects of the Section 112 criteria for sufficient disclosure (the requirements relating to "enablement" and "written description") are the subject of recent developments in the case law in this area and also present interesting issues for the field of veterinary medicine, especially regarding the question of how broad a claim one can obtain when only a very limited number of examples (or species) are disclosed.

\section{The Enablement Requirement under 35 U.S.C. $§ 112$}

In the U.S., the standard for evaluating enablement is whether the patent specification teaches those skilled in the relevant art to make and use the claimed invention without "undue experimentation"(7). With regard to the factors to be considered in determining whether "undue experimentation" is required, reference is usually made to the landmark case of In re Wands, 858 F. 2nd 731 (Fed. Cir. 1988). In the Wands case, the patent claims at issue related to immunoassay methods for the detection of hepatitis B surface antigens using high-affinity $\operatorname{IgM}$ monoclonal antibodies, and the issue was whether undue experimentation would have been required to produce the monoclonal antibodies. The patent applicant asserted that his invention was enabled because the monoclonal antibodies needed to perform the immunoassays could "easily be made from readily available starting materials using methods that are well known in the monoclonal antibody art"(8). The court agreed and noted that there was no challenge to applicant's contention that the starting materials (mice, HBsAg antigen and myeloma cells) were available to the public. Most importantly for future cases, the court set forth the following eight factors to consider in determining whether "undue experimentation" would be needed:

1. The quantity of experiments necessary;

2. The amount of direction or guidance presented;

3. The presence or absence of working examples;

4. The nature of the invention;

5. The state of the prior art;

6. The relative skill of those in the art;

7. The predictability or unpredictability in the relevant field;

8. The breadth of the claims.

The relative weight a court will give to each factor will usually depend upon the facts of the particular case in suit.

Subsequent to the Wands case, the court in In re Wright, 999 F.2d 1557 (Fed. Cir. 1993), dealt with enablement issues concerning vaccine claims in the animal health field. In order of expanding scope, the claims at issue in Wright were directed to vaccines against the specific Prague Avian Sarcoma Virus (PrASV) in chickens; vaccines against all avian RNA viruses; and vaccines against all RNA viruses. However, the patent application gave only "a single working example" of a vaccine (specifically, a vaccine against PrASV in chickens). The court held that the narrower claims directed to vaccines against the specific chicken virus were allowable, but the court also held that the claims drawn to vaccines 
against any and all avian RNA viruses, as well as the claims directed to any and all RNA viruses, were not enabled. The court cited examples such as the general difficulty in developing RNA virus vaccines (such as AIDS vaccines) and reasoned that one working example was simply insufficient given the lack of predictability due to the mutation and diversity of these RNA viruses. Moreover, the court noted there was nothing in the record to establish that an immune response caused by an antigenic envelope protein would have been sufficient to rise to the level of an "immunoprotective" response (9).

The patent applicants in In re Wright could have improved their chances of obtaining broader claim scope if they had more working examples, especially in multiple species. Even if broad claims to "all RNA viruses" might not have been realistic, additional working examples in a variety of avian species could possibly have led to a "genus" claim drawn to vaccines against a broader group of RNA viruses (e.g., vaccines against a genus of RNA viruses in poultry). Here we see a potential example of how the animal health field might uniquely lend itself to interesting opportunities for obtaining "genus" claims within a given grouping of animals.

\section{The "Written Description" Requirement under 35 USC Section 112}

In the areas of biotechnology and the life sciences, one of the landmark cases regarding the written description requirement is Regents of the Univ. of Cal. v. Eli Lilly, 119 F.3d 1559 (Fed. Cir. 1997). In that case, the University presented claims covering the entire genus of "vertebrate" cDNAs encoding insulin (in addition to claims drawn to "mammalian insulin cDNA" and narrower claims drawn specifically to "human insulin DNA"). However, the University's patent application disclosed only rat cDNA, along with the amino acid sequence for human insulin, and a method for isolating human DNA using the rat sequence. In ruling that the University's claims failed to meet the written description requirement and were therefore unpatentable, the court stated that a "description of rat insulin cDNA is not a description of the broad classes of vertebrate or mammalian insulin cDNA,"(10) Citing Fiers v. Revel, 984 F.2d 1164, 1171 (Fed. Cir. 1993), the court reiterated its belief that claims to a cDNA require "a kind of specificity usually achieved by means of the recitation of the sequence of nucleotides that make up the DNA" (11).

The rationale of the Lilly case was subsequently incorporated into Guideline No. 17 of the U.S. Patent and Trademark Office's Synopsis of Application of Written Description Guidelines (12). Guideline No. 17 (which could be of particular relevance with regard to "cross-species" issues in field of veterinary medicine) indicates that an example based on a lone species (rat cDNA) which was "not representative" of the claimed genus (mammalian cDNA) would not be sufficient to meet the $\$ 112$ written description requirement.

A different result, however, was reached in the case of Amgen v. Hoechst, 314 F.3d 1313 (Fed. Cir. 2003), where the technical subject matter involved host cells rather than cDNAs. In this case, Amgen had claims broadly directed to "vertebrate" host cells and "mammalian" host cells, but Amgen's examples were limited to monkey cells and Chinese hamster ovary cells. Nevertheless, the court held that since host cells are very different from cDNA (in terms of readily conveying distinguishing information concerning identity), Amgen's disclosure satisfied the written description test because one skilled in the art could easily recognize the identity of the members of the claimed genus (13). Furthermore, when it came to the enablement requirement, the court relied primarily on expert testimony in ruling that Amgen's broad claims to "vertebrate" and "mammalian" host cells were sufficiently enabled by disclosure of just the two species of mammalian cells (14).

Turning to antibody technology, the patent application in the case of Noelle v. Lederman, 355 F.3d 1343 (Fed. Cir. 2004), had claims drawn to human CD40CR antibodies and mammalian CD40CR antibodies, but the original disclosure only described and claimed mouse CD40CR antibodies. Here, the court applied the standard set in Lilly and ruled that patent applicant's specific, narrow disclosure of mouse antigen was not sufficient to support a patent claim for a more generic scope of coverage for CD40CR antibodies (especially when it comes to other species). The court held that antibody claims must be fully characterized for there to be proper written description, noting that "as long as applicant has disclosed a fully characterized antigen, either by its structure, formula, chemical name, or physical properties, or by deposit of the antibody in a public depository, the applicant can then claim an antibody by its binding affinity to that described antigen" (15).

\section{RECENT DEVELOPMENTS IN THE LAW OF OBVIOUSNESS THAT COULD IMPACT PATENTING IN THE FIELD OF VETERINARY MEDICINE}

\section{Background on the Development of the Law Pertaining to Obviousness}

In the U.S., the law pertaining to obviousness is codified in 35 U.S.C. $\S 103$, which provides in pertinent part:

A patent may not be obtained... if the differences between the subject matter sought to be patented and the prior art are such that the subject matter as a whole would have been obvious at the time the invention was made to a person having ordinary skill in the art...

In the case of Graham v John Deere, 383 U.S. 1 (1966), the U.S. Supreme Court set out the following three steps for assessing whether the subject matter of a patent claim is obvious:

- Determine the scope and content of the prior art,

- Ascertain the differences between the prior art and claims at issue, and

- Assess the level of ordinary skill in the pertinent art.

Beyond this basic three-step test, the Supreme Court also noted that, where relevant, secondary considerations such as the following could also be used:

- Commercial success of the invention,

- Long felt but unsolved need for the present invention, and

- The failure of others.

Graham v Deere remained the seminal case on obviousness throughout the four decades since its issuance. In recent 
years, however, criticism grew that the Court of Appeals for the Federal Circuit (the main appeals court in patent cases) was interpreting the Graham $v$ Deere test in a way that unfairly raised the bar for parties trying to invalidate patents. In particular, the Federal Circuit Court was criticized for rigidly requiring parties to demonstrate a specific "teaching, suggestion, or motivation" to combine references when alleging obviousness (a test often referred to as the "TSM" test).

The issue of the TSM test was finally argued at the Supreme Court on November 28, 2006, in the much-anticipated case of KSR International v. Teleflex (16). In KSR, the question before the Supreme Court was whether a claimed invention can be obvious, and therefore unpatentable under 35 U.S.C. 103(a), without proof of some "teaching, suggestion, or motivation" to modify or combine the prior art in the manner claimed. KSR (the accused infringer) argued that the claimed invention of the patent in suit (the combination of a known adjustable gas pedal with a known electronic throttle control) merely represented an obvious combination of existing devices. In response, the party asserting the patent (Teleflex) argued that the Federal Circuit case law pertaining to obviousness required a party to demonstrate a specific teaching, suggestion or motivation to combine reference teachings, and in this case there was no evidence of a specific teaching, suggestion or motivation to combine the known gas pedal with the known electronic control.

On April 30, 2007, the Supreme Court issued its decision reversing the Federal Circuit's "rigid" approach and finding that the claimed combination was obvious. Noting that courts should be free to take account of the "inferences and creative steps that a person of ordinary skill in the art would employ," the Supreme Court held that the analysis of obviousness "need not seek out precise teachings directed to the specific subject matter of the challenged claim" (17). In reaching its decision, the Supreme Court pointed out that courts do not have to ignore common sense, observing that "familiar items may have obvious uses beyond their primary purposes, and in many cases a person of ordinary skill will be able to fit the teachings of multiple patents together like pieces of a puzzle" (18).

At the same time, the Court was cognizant that patent examiners and other parties asserting obviousness of a claimed invention should not be allowed to use hindsight to link two distant references together without any reasonable basis to do so. Accordingly, the Court cautioned that assertions of obviousness "cannot be sustained by mere conclusory statements; instead, there must be some articulated reasoning with some rational underpinning to support the legal conclusion of obviousness". See KSR International Co. v. Teleflex Inc., 127 S. Ct. 1727, 1741 (2007) (quoting In re Kahn, 441 F. 3d 977, 988 (Fed. Cir. 2006)).

On May 3, 2007, three days after the KSR decision, the Deputy Commissioner for Patent Operations at the U.S. Patent and Trademark Office (USPTO) issued an interim statement noting, inter alia, that:

- "The Supreme Court in KSR did not totally reject the use of 'teaching, suggestion, or motivation' as a factor in the obviousness analysis. Rather, the Court recognized that a showing of 'teaching, suggestion, or motivation' to combine the prior art to meet the claimed subject matter could provide a helpful insight in determining whether the claimed subject matter is obvious" (19).

- "The Court rejected a rigid application of the "teaching, suggestion, or motivation' (TSM) test” (19).

- "The Court noted that the analysis supporting a rejection under 35 U.S.C. \$103(a) should be made explicit, and that it was 'important to identify a reason that would have prompted a person of ordinary skill in the relevant field to combine the (prior art) elements' in the manner claimed" (19).

In view of this last point, the Deputy Commissioner's interim statement concluded that:
"in formulating a rejection under 35 U.S.C. \$103(a) based upon a combination of prior art elements, it remains necessary for patent examiners to identify the reason why a person of ordinary skill in the art would have combined the prior art elements in the manner claimed" (19).

Although the technology at issue in the KSR case related to the design of auto parts, the Supreme Court's ruling on the issue of obviousness is expected to shape the future of patenting in the life sciences. In particular, one can anticipate that it will be now become easier to argue that a patent claim is obvious. Furthermore, to rebut a "prima facie" case of obviousness, patent applicants in the future will likely have to meet a higher standard of proof and likely need to rely on strong evidence, such as:

1. Test data or other tangible evidence showing unexpectedly improved properties;

2. Test data or other tangible evidence showing that the claimed invention has unforeseeable properties not found in the prior art;

3. Arguments or evidence that the prior art shows a bias against trying the newly claimed combination.

In Europe, where "obviousness" is known as "lack of inventive step" under the European Patent Convention (EPC), the case law has undergone its own unique evolution with respect to how the issue is analyzed. In general, the evaluation of "inventive step" in Europe starts with the identification of the "closest prior art" and the "technical problem to be solved". This is then followed by an analysis of whether the technical solution to the problem represents an unexpected or "non-obvious" advance over the "closest prior art" (when combined with either a second prior art reference or common general knowledge in the relevant art). A thorough review of the European case law on inventive step can be found in Case Law of the Boards of Appeal of the European Patent Office, pp. 120-168 (5th Ed. 2006) (20). With particular regard to the life sciences, it is worth noting cases such as Modifying Plant Cells/MYCOGEN (T 694/92; OJ EPO 1997, 408), Vaccines/GENENTECH (T 187/93; 1997), and Triazole/ AGREVO (T 939/92 OJ EPO 1996/309), where there is an interesting interplay between the "inventive step" requirement of Article $56 \mathrm{EPC}$ and the "sufficiency of disclosure" requirement of Article 83 EPC. In particular, these cases show that it has been the practice of the European Patent Office, under the so-called "problem and solution" approach, to evaluate whether or not the problem in a given case has 
been solved across the full scope of the claims, and then to limit a patent proprietor's claims to a scope commensurate with the proprietor's actual contribution to the art.

\section{Examples of Special Situations in the Field of Veterinary Medicine Where the Issue of Obviousness Could Come Into Play}

When evaluating obviousness under the patent laws, some of the more interesting situations that could arise in the veterinary field are ones involving "cross-species" scenarios. These are situations where the therapeutic use of a given active ingredient or class of active ingredients is already known in one animal species, and the new invention will use the same active ingredient (or a member of the known class of active ingredients) in a second animal species (e.g., a situation where it is known to use Drug $X$ in a dog and the claimed invention is to use the same Drug $X$ in a cat; or a situation where it is known to use a specific class of drugs in humans and the claimed invention is to use a particular member of this class of drugs in an animal).

In situations such as these, the most favorable scenario for the patent applicant is where the prior art publications teach, or at least suggest, an actual bias against using the therapeutic in the newly claimed species of animal. A hypothetical example of this scenario would be as follows:

1. The prior art shows that a certain class of compounds can be used successfully in dogs, but several compounds within this class have previously been shown not to work in cats (or better yet for the patent applicant, were toxic in cats), and

2. The new invention is the paradoxical finding that a novel compound within the known class of compounds turns out to be perfectly safe and effective in cats.

This type of favorable prior art landscape is sometimes referred to among patent practitioners as a "teaching away" or a "prejudice" in the art and will usually be the easiest argument to make if a patent applicant is fortunate enough to have such a favorable prior art landscape as the backdrop for the newly claimed invention (in this case, a novel compound with surprising properties).

The more difficult situation is where the prior art shows use of a compound or class of compounds in multiple species of animals and the new invention is in a species of animal where the drug or class of drugs has not yet been tried. In situations such as these, the patent applicant should attempt to identify a reason why there might be a bias not to use the drug in the new species. To support such an argument, the applicant should show (preferably through the use of strong data) that the claimed invention yields surprising or unexpectedly superior results such that one of ordinary skill in the art at the time would not have had a reasonable expectation of such success in the new animal species.

For examples of "cross-species" scenarios, reference can be made to U.S. Patent No. 6,716,423 and U.S. Patent No. 5,750,112. U.S. Patent 6,716,423 relates to methods of vaccinating a cow against a particular pathogen, Neospora, which was first isolated and identified in dogs, while U.S. Patent 5,750,112 relates to a canine coronavirus vaccine employing a feline enteric coronavirus. In the case of U.S.
Patent 5,750,112, there was prior art showing that crossprotective studies with feline enteric coronavirus offered little protection in certain heterologous species (e.g., in pigs), thus providing a bias in the prior art against cross-species efficacy. Among other things, the patent applicant argued that the art of developing vaccines to prevent canine corona virus infections in dogs was unpredictable based on the antigenical relationship of the coronaviradae viruses.

\section{POTENTIAL ISSUES RELATED TO PATENTS COVERING ASSAYS}

An interesting issue with potential application to the veterinary medicine field concerns the question of patents in the area of assays for analyzing the effects of drugs.

In the U.S. and many other countries in the world, it is well established that assays and methods of carrying out assays can properly be the subject matter of patents (provided all the standard criteria of patentability are met). Thus, in a situation where a patentee has been granted claims covering an assay which is required by a regulatory agency to be used in connection with the administration of a given therapy, a question could arise as to what kind of remedies-such as lost profits, reasonable royalties, injunctive relief, etc.- the patentee could be entitled to receive if the claimed assay is indeed carried out by other parties in order to comply with regulatory requirements.

With regard to clinical testing during the drug approval process, there is often a valid exception to infringement under Section 271(e)(1) of the U.S. Patent Statute (21). Section 271 (e)(1) provides a "safe harbor" exemption from patent infringement for "uses reasonably related to the development and submission of information under a Federal law which regulates...drugs or veterinary biological products," and this special exemption has been given a fairly broad interpretation under recent case law.(22) However, once a party commercializes a therapeutic, that party can no longer use the Section 271(e)(1) exemption as a defense. It also would not be a defense simply to say that it is the clinician or veterinarian who is the infringer and not the company that supplies the therapeutic product. This is because the company selling the product commercially could be accused of inducing infringement under 35 U.S.C. $\S 271(b)$ or contributing to infringement under 35 U.S.C. $\S 271(\mathrm{c})$. Although it is beyond the scope of this article to speculate on how all this might be played out in court and what remedies might or might not be available, there are some court cases that may be of interest in this analysis. See, e.g., Hybritech Inc. v. Abbott Laboratories, 849 F. 2d. 1446 (Fed. Cir. 1988), where the defendant's infringing cancer and hepatitis test kits were not included in the preliminary injunction order against the defendant since the patentee did not offer such kits and there were no other suppliers at the time. Moreover, the U.S. Supreme Court has recently issued a landmark decision on remedies in patent infringement cases, ruling there is no longer a "general rule" in patent cases that courts will almost always issue permanent injunctions against infringement. Specifically, in eBay, Inc. v. MercExchange, L.L.C, 547 U.S. _, 126 S. Ct. 1837 (2006), the Supreme Court held that in patent cases, like all other types of cases, permanent injunctions can only be issued where the 
remedy is appropriate in light of equitable principles. This means that the remedy must be assessed under the wellestablished four-factor test used in all other cases, whereby a plaintiff/patentee seeking a permanent injunction is required to show that:

1. The patentee will suffer irreparable harm,

2. Standard legal remedies such as monetary damages are inadequate to compensate for the injury,

3. A permanent injunction is warranted in view of the balance of hardships (between patentee and infringer), and

4. A permanent injunction would not be against the public interest.

Thus, with particular regard to the fourth factor, the more an accused infringer can argue that injunctive relief is against the public interest (e.g., the accused product is a lifesaving cure that is not available from any other source), the greater chance there is under the new case law that a judge might refuse to order an injunction (despite infringement of a valid patent).

Within the field of veterinary pharmaceuticals, this issue has a unique twist. When a drug is approved for use in foodproducing animals, residue limits and withdrawal times are established to ensure the safety of the animal-derived food (e.g., eggs, milk, and meat) for human consumption. The component of the application that establishes human food safety must contain an analytical method that has been properly validated. The performance characteristics of that method are then integrated into the establishment of a withdrawal time (i.e., the time between the last dose and when the animal-derived food product is considered to be safe for human consumption). Interestingly, although the analytical method would be considered as part of the product dossier, the analytical method becomes an integral component of the drug monitoring program and must be the method used by any laboratory involved in the monitoring of food for "violative residues". Furthermore, in legal proceedings in the U.S. associated with prosecuting parties for marketing drug-tainted food, data generated using the FDA-approved analytical method are relied upon to support the prosecutions $(23,24)$.

\section{SITUATIONS WHERE THERE ARE ACTUAL DIFFERENCES IN THE LAW IN THE CASE OF VETERINARY MEDICINE}

In research compiled for this article, very few examples have been uncovered where there are actual differences in the law per se when it comes to the veterinary field. Perhaps the most interesting examples can be found in the area of U.S. law pertaining to patent term restoration and the interplay of this area of patent law with U.S. regulatory law as embodied in the so-called "Hatch-Waxman Act" (in the field of human medicine) and the Generic Animal Drug and Patent Term Restoration Act (in the field of veterinary medicine).

\section{Overview of the Hatch-Waxman Act and the Generic Animal Drug and Patent Term Restoration Act (GADPTR)}

The original Hatch-Waxman legislation was passed in 1984 as a compromise between pioneer pharmaceutical companies and generic companies. The pioneer companies were concerned that they were spending enormous sums of money to develop each new drug, yet the duration of time from drug discovery to commercialization was often more than 10 years - thereby eroding valuable patent term. The generic companies, on the other hand, argued that they could not get on the market until years after the patent expiration. This was because of the famous 1984 case, Roche v. Bolar, 733 F.2d 858 (Fed. Cir. 1984), which held that testing and development in pursuit of regulatory approval constituted infringement even though the generic company was willing to wait for the patent to expire before commercializing the product.

These developments provided the foundation for the Hatch-Waxman legislation, whereby generic companies were given the benefit of earlier entry possibilities in exchange for pioneer companies being able to retrieve, to a limited extent, some of the lost years of valuable patent life that were unused due to the regulatory approval process.

In 1988, the Hatch-Waxman legal framework was, for the most part, extended to the field of veterinary medicine through enactment of the Generic Animal Drug and Patent Term Restoration Act (GADPTR) (25). Like Hatch-Waxman on the human side, the GADPTR gave generic companies the benefit of earlier entry possibilities in exchange for pioneer companies being able to retrieve some of the lost years of valuable patent life that were unused due to the regulatory approval process. However, there are a few significant differences between the statutory provisions on the human side and the statutory provisions on the veterinary side (as discussed below):

\section{Statutory Differences Under the Generic Animal Drug and Patent Term Restoration Act}

The Option for a Patentee in the Animal Health Field to Take its Patent Term Extension for a Food-Producing Animal Indication Even if a Companion Animal Indication is Approved First

The patent term restoration statute makes clear that a patent can only be extended once-and, generally, only for the first approved use (26). However, this would present a potential dilemma for an animal health company seeking regulatory approval in both companion animals and foodproducing animals in cases where the company obtains its first approval for a companion animal indication while a much more lucrative indication for food-producing animals is still pending (e.g., a company's new antibiotic is approved for dogs before it is approved for cows). To remove this potential dilemma, there is a unique provision in the patent term restoration statute that provides a patentee in the animal health area the important option of actually deferring its onetime opportunity for patent term extension until its approval for the food-producing animal indication comes through. This represents a very unusual statutory exception to the general rule that a patent can only be extended for the first approval. No such exceptions exist for human therapeutics.

\section{Genetically Engineered Animal Drugs are Expressly Excluded from Patent Term Restoration under GADPTR}

Unlike the relatively broader opportunities for patent term restoration in the case of human therapeutics, the law in 
the animal health area expressly excludes patentees from obtaining patent term restoration for genetically engineered animal drugs (i.e., drugs that were "primarily manufactured using recombinant DNA, recombinant RNA, hybridoma technology, or other processes involving site-specific genetic manipulation techniques") (25). There is no such exclusion in the case of human therapeutics.

Genetically Engineered Animal Drugs are Expressly Excluded from the "Safe Harbor" Provisions in 35 U.S.C. $\$ 271($ e)(1)

The "safe harbor" exemptions from patent infringement provided in 35 U.S.C. $\$ 271$ (e)(1) for "uses reasonably related to the development and submission of information under a Federal law which regulates...drugs or veterinary biological products" applies for both human and animal drugs. However, unlike human drugs, animal drugs or veterinary biologics are expressly excluded from the safe harbor if they were "primarily manufactured using recombinant DNA, recombinant RNA, hybridoma technology, or other processes involving sitespecific genetic manipulation techniques".

Obtaining One Patent Extension for an Active Ingredient in a Human Indication and then Obtaining a Second Patent Extension for the Same Active Ingredient in an Animal Indication

A question sometimes arises as to whether a "second patent term restoration" is possible for an animal health approval when the same active ingredient has already been extended for a human therapeutic product. In general, the patent term restoration statute contains strong prohibitions against obtaining a second patent term restoration for the same active ingredient (26). However, if one reads carefully through all the statutory prohibitions, the possibility for the following special scenario can be seen: Assume that a company has two patents: Patent A covering the use of Compound $\mathrm{X}$ in a human indication (as approved under Section 505 of the Federal Food, Drug, and Cosmetic Act ("FDCA")) and Patent B covering use of the same Compound $\mathrm{X}$ in an animal indication (as approved under Section 512 of the FDCA). Then, in this particular situation (assuming all the other conditions are met), the company can obtain one extension - on Patent A-based on the human indication, plus an additional extension-on Patent B-based on the veterinary indication. Key to this scenario, of course, is the assumption that Patent A does not extend in scope to cover the veterinary use and Patent B does not extend in scope to cover the human use.

\section{Other Statutory Differences Between Laws Applying to Human Products and Laws Applying to Veterinary Products}

\section{No "Pediatric Exclusivity" for Animal Drugs}

In the U.S., human drugs meeting certain specified requirements involving additional testing for pediatric use can qualify for an extra six months exclusivity (in addition to all other applicable exclusivity periods) (27), but there is no corresponding "pediatric exclusivity" for animal drugs.
Orphan Drug Status for Human Drugs vs. "MUMS” Status for Animal Drugs

In the U.S., human drugs meeting all the requisite conditions (e.g., rare diseases affecting fewer then 200,000 patients) can obtain a so-called "Orphan Drug" designation" under the Orphan Drug Act (28), whereby the holder is entitled to several specified benefits such as the possibility for tax credits and seven years of exclusivity with respect to the specified orphan indication. The Orphan Drug Act does not extend to animal drugs. However, animal drugs meeting certain criteria have the possibility to obtain a so-called Minor Use/Minor Species (MUMS) designation for qualified "minor species" (e.g., goats, sheep, fish, etc.) or for uncommon "minor uses" in the major animal groups (cattle, cats, dogs, swine, poultry, etc.). The MUMS designation also provides seven years of marketing exclusivity for that indication (29), but does not provide the basis for patent extensions or tax credits.

\section{Pharmaceutical Patent "Springboarding” in Australia}

Australian law provides a special "springboarding" safe harbor exemption from patent infringement whereby clinical testing of a human pharmaceutical product by an unlicensed party is permitted-during the term of the relevant patentfor the purpose of obtaining regulatory approval of a generic version of the patented product. However, unlike the provisions for clinical trials in the U.S. and Europe where most veterinary products enjoy safe harbors relatively similar to those enjoyed by human products, this particular "springboarding" safe harbor in Australia does not apply to pharmaceuticals in the veterinary field and thus represents a stark example of where the law for veterinary pharmaceuticals differs from the law for human pharmaceuticals.

\section{CONCLUSION}

The author continues to search for examples where provisions in a nation's patent laws might have unique application in the case of veterinary medicine and would welcome learning of further examples that readers may have encountered. Readers may also want to take a closer look at the areas of law where the human and veterinary fields diverge and consider whether the divergence is justified in each case.

\section{ACKNOWLEDGMENT}

The views expressed herein are solely the views of the author and do not necessarily reflect the views of ScheringPlough Corporation.

\section{REFERENCES}

1. 35 U.S.C. $\$ 101$

2. Guidelines for Examination of Applications for Compliance With the Utility Requirement, 66 Fed. Reg. 1092, 1098 (Jan. 2, 2001).

3. 35 U.S.C. $\$ 102$ 
4. 35 U.S.C. $\$ 103$

5. Convention on the Grant of European Patents, art. 56, October 5, 1973, 1065 U.N.T.S. 254 (hereinafter referred to as "European Patent Convention" or "EPC"). Available at: http://www.euro pean-patent-office.org/legal/epc/e/ma1.html. Accessed September 30, 2007.

6. Vas Cath Inc. v. Mahurkar, 935 F.2d 1555 (Fed. Cir. 1991).

7. In re Vaeck, 947 F.2d 488, 495 (Fed. Cir, 1991).

8. In re Wands, 858 F. 2nd 731, 736 (Fed. Cir. 1988).

9. In re Wright, 999 F.2d 1557, 1568 (Fed. Cir. 1993).

10. Regents of the Univ. of Cal. v. Eli Lilly, 119 F.3d 1559, 1568 (Fed. Cir. 1997).

11. Regents of the Univ. of Cal. v. Eli Lilly, 119 F.3d 1559, 1569 (Fed. Cir. 1997).

12. Synopsis of Application of Written Description Guidelines. Available at: http://www.uspto.gov/web/menu/written.pdf. Accessed November 15, 2006.

13. Amgen v.Hoechst, 314 F.3d at 1332-33 (Fed. Cir. 2003).

14. Amgen v.Hoechst, 314 F.3d at 1334-37 (Fed. Cir. 2003).

15. Noelle v. Lederman, 355 F.3d 1343, 1349 (Fed. Cir. 2004).

16. KSR International Co. v. Teleflex Inc., 127 S. Ct. 1727 (2007).

17. KSR International Co. v. Teleflex Inc., 127 S. Ct. 1727, 1741 (2007).

18. KSR International Co. v. Teleflex Inc., 127 S. Ct. 1727, 1742 (2007)

19. USPTO Memo available at: http://www.ipwatchdog.com/patents/ uspto_obviousness_memo_5_3_2007.pdf. Accessed June 21, 2007.
20. Case Law of the Boards of Appeal of the European Patent Office, pp. 120-168, published by the European Patent Office, Druckerei Ferdinand Berger \& Söhne, Horn, Austria (5th Ed. 2006), ISBN 3-89605-085-2. Available at: http://www.epo.org/patents/law/ legal-texts/case-law.html. Accessed June 21, 2007.

21. 35 U.S.C. $\$ 271(\mathrm{e})(1)$.

22. Merck KGaA v. Integra LifeSciences Ltd., 545 U.S. 193 (2005).

23. M. Martinez, L. Friedlander, R. Condon et al. Response to criticisms of the US FDA parametric approach for withdrawal time estimation: rebuttal and comparison to the nonparametric method proposed by Concordet and Toutain $J$ Vet Pharmacol Ther 23:21-35 (2000)

24. FDA/CVM. Guidance for Industry: General Principles for Evaluating the Safety of Compounds Used in (codified at $21 \mathrm{U}$. S.C. $\$ \S 301,321$, Food-Producing Animals. FDA: Rockville, MD: 2006.

25. Generic Animal Drug and Patent Term Restoration Act, Pub. L. No. 100-670, 102 Stat. at 3971 (1988) 353; 28 U.S.C. \$2201; 35 U. S.C. $\S \S 156,271)$.

26. 35 U.S.C. $\$ 156$.

27. 21 U.S.C. $\$ 355$ a.

28. 21 U.S.C. $\$ 360$ aa et seq.

29. Minor Use and Minor Species (MUMS) Animal Health Act, August 2, 2004. Available at: http://www.fda.gov/cvm/Documents/ S741Enrolled.pdf. Accessed April 28, 2007. 